\title{
HYDROCARBON-BEARING SANDSTONE IN THE UPPER JURASSIC NAKNEK FORMATION ON THE SOUTH SHORE OF KAMISHAK BAY
}

by

Richard G. Stanley ${ }^{1}$, Trystan M. Herriott ${ }^{2}$, Kenneth P. Helmold ${ }^{3}$, Robert J. Gillis ${ }^{2}$, and Paul G. Lillis ${ }^{1}$

The presence of an active petroleum system in Kamishak Bay is demonstrated by an outcrop of hydrocarbon-bearing sandstone in the Upper Jurassic Naknek Formation near the south shore of the bay (fig. 1). The outcrop is about $140 \mathrm{~km}$ southwest of Homer on a small, unnamed island near the mouth of the Douglas River (fig. 17). The existence of this outcrop was kindly reported to us by Les Magoon (U.S. Geological Survey, emeritus), who also provided a topographic map showing its exact position. The outcrop was mentioned very briefly in publications by Magoon and others (1975, p. 19) and by Lyle and Morehouse (1977, p. E-1), but to our knowledge there are no detailed descriptions of this outcrop or its hydrocarbons in the published scientific literature.

The Naknek Formation at this locality consists mainly of quartz-bearing, cross-stratified, and bioturbated sandstone with locally abundant molluscan shells, and plant debris (figs. 19-24). Discrete trace fossils include Macaronichnus (fig. 23), Planolites (fig. 24), Fugichnia, and probable Skolithos. Based on sedimentary facies and ichnofauna, we interpret this section as moderate- to high-energy marine shoreface deposits. The quartzose sand may have been derived from erosion of uplifted granitic rocks in the vicinity of the modern Aleutian Range. Freshly broken pieces of the hydrocarbon-bearing sandstone have a strong-yet fleeting-kerosene-like odor. Samples of the hydrocarbons were collected during helicopter-assisted fieldwork in 2012 and submitted to the U.S. Geological Survey organic geochemical laboratory in Denver, Colorado, for analysis. The results of these analyses will be used to evaluate the hypothesis that the hydrocarbons were derived from petroleum source rocks in the Middle Jurassic Tuxedni Group, the principal source of oil and associated gas in the Cook Inlet basin (Magoon and Anders, 1992; Magoon, 1994; Lillis and Stanley, 2011; LePain and others, 2012). We also measured and described a detailed 45-m-thick stratigraphic section (figs. 17 and 18) and collected numerous photographs and rock samples for use in analyzing the sedimentology, sedimentary petrology, and reservoir characteristics of the Naknek Formation at this location. A detailed report regarding this work is planned for publication during 2013.

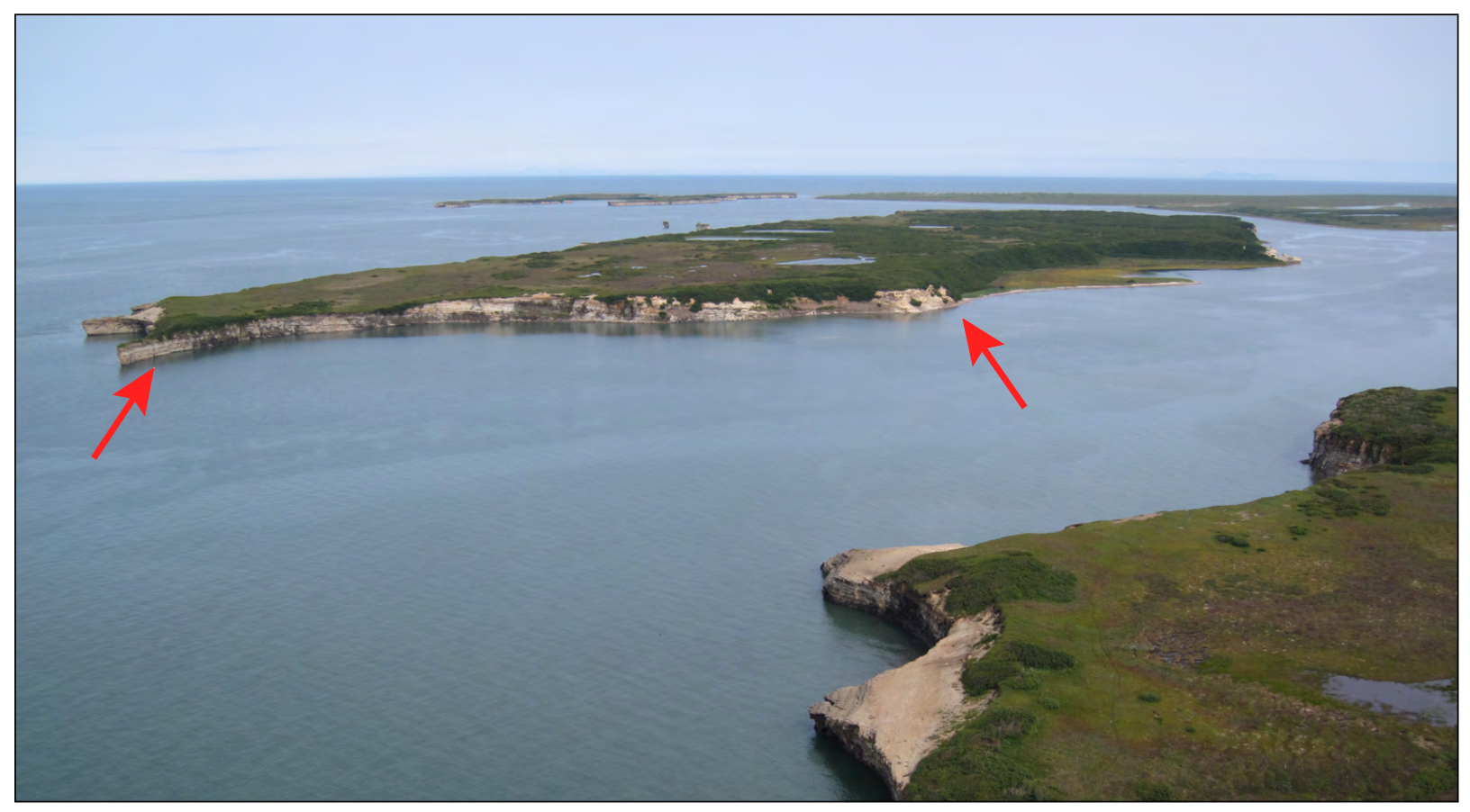

Figure 17. View to the east across the mouth of the Douglas River toward an unnamed island, with Kamishak Bay in the distance. On the island, light-colored sandstone beds of the Upper Jurassic Naknek Formation dip gently upstream (toward right of photo) in low cliffs along the Douglas River, which here is about $500 \mathrm{~m}$ wide. Our detailed, 45-m-thick measured section lies between the two red arrows. The stratigraphically highest beds in these cliffs (tan-colored interval near red arrow at right) are hydrocarbon bearing and have a strong, kerosene-like odor. Photo by Rick Stanley (USGS), 2012.

${ }^{1}$ U.S. Geological Survey, 345 Middlefield Road Mail Stop 969, Menlo Park CA 94025-3561

${ }^{2}$ Alaska Division of Geological \& Geophysical Surveys, 3354 College Rd., Fairbanks, AK 97709-3707

${ }^{3}$ Alaska Division of Oil \& Gas, 550 W. 7th Ave., Suite 800, Anchorage, AK 99501-3560 


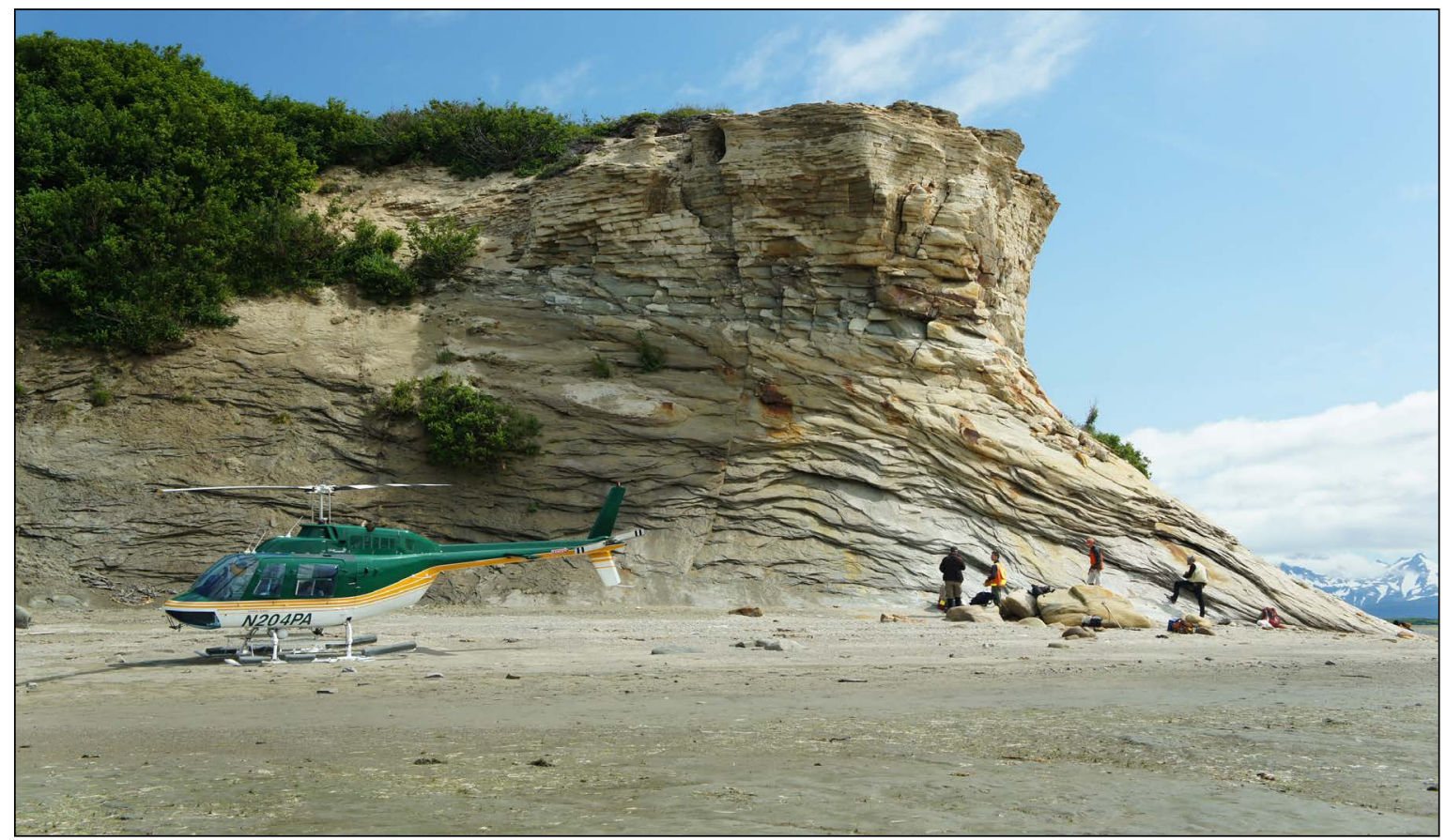

Figure 18. View to the east of hydrocarbon-bearing sandstone outcrop in the Naknek Formation. The top of the cliff is 12-15 m above the beach. A rock sample (approximately $33 \mathrm{~m}$ stratigraphically above the base of the measured section) was collected near the location of the four geologists in photo and submitted to the U.S. Geological Survey organic geochemical laboratory in Denver, Colorado, for analysis of the hydrocarbons.

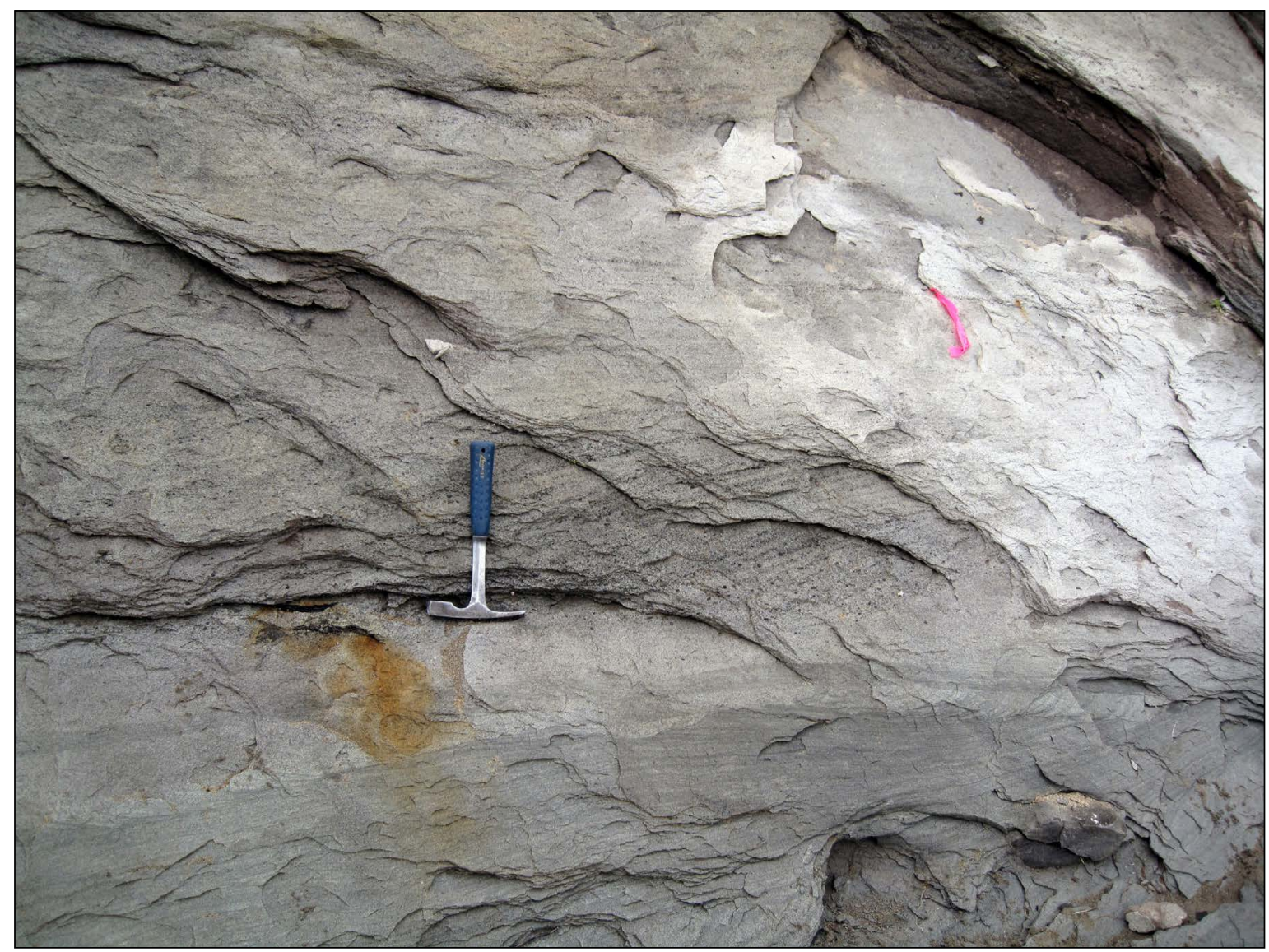

Figure 19. Detail of hydrocarbon-bearing sandstone outcrop, showing coarse, granular texture and cross-stratification. Rock hammer is about $30 \mathrm{~cm}$ long. Photo by Rick Stanley (USGS), 2012. 


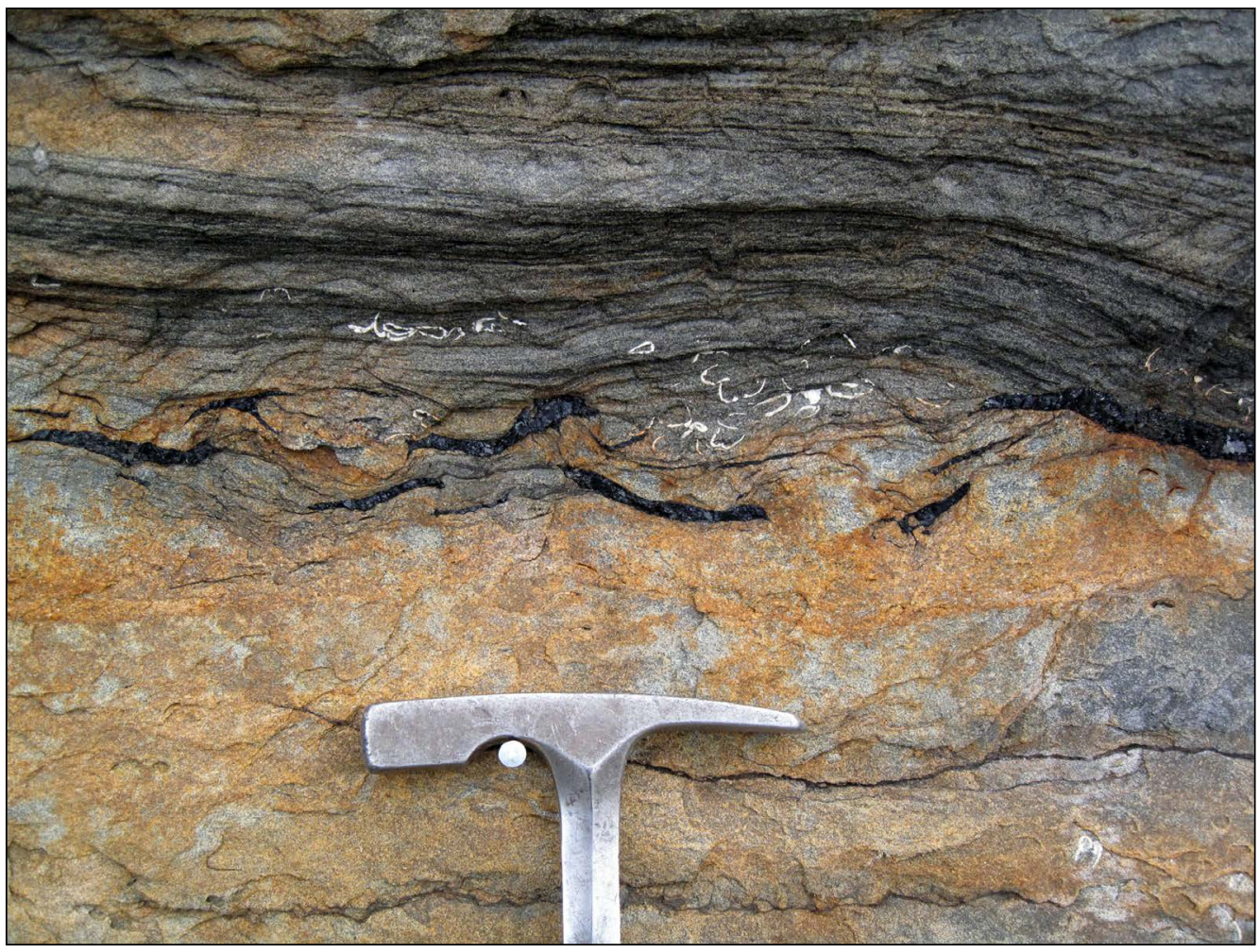

Figure 20. Detail of outcrop about 20-25 m stratigraphically below the hydrocarbon-bearing sandstone in figure 3. Orange-brown-weathering bioturbated sandstone with mottled texture and color is overlain by darker colored, well laminated sandstone. Shiny black fragments are coalified plant material; white molluscan shells and shell fragments are also visible. Photo by Rick Stanley (USGS), 2012.

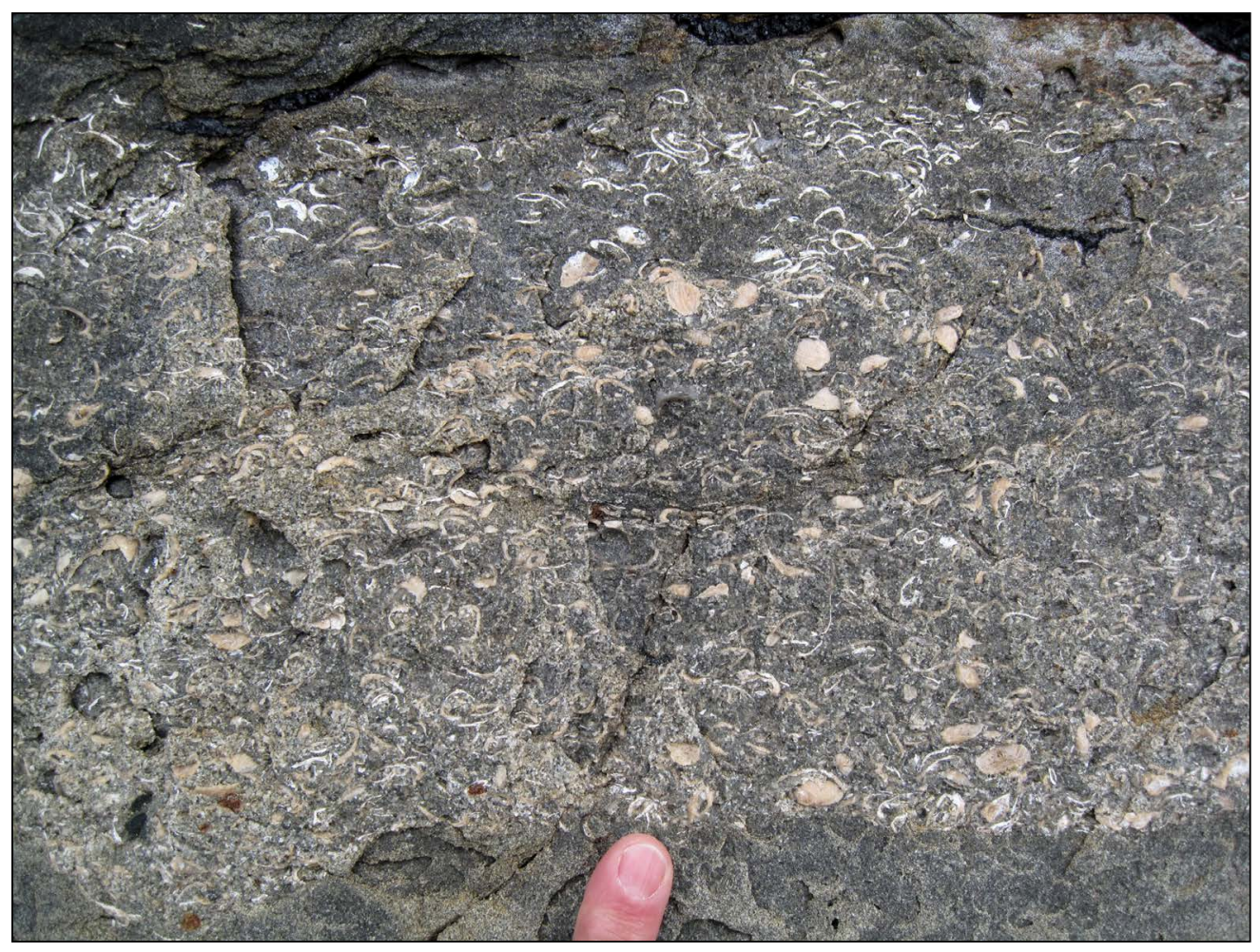

Figure 21. Detail of outcrop about $30 \mathrm{~m}$ stratigraphically below the hydrocarbon-bearing sandstone in figure 3, showing a coquina bed of molluscan shells and shell fragments. Photo by Rick Stanley (USGS), 2012. 


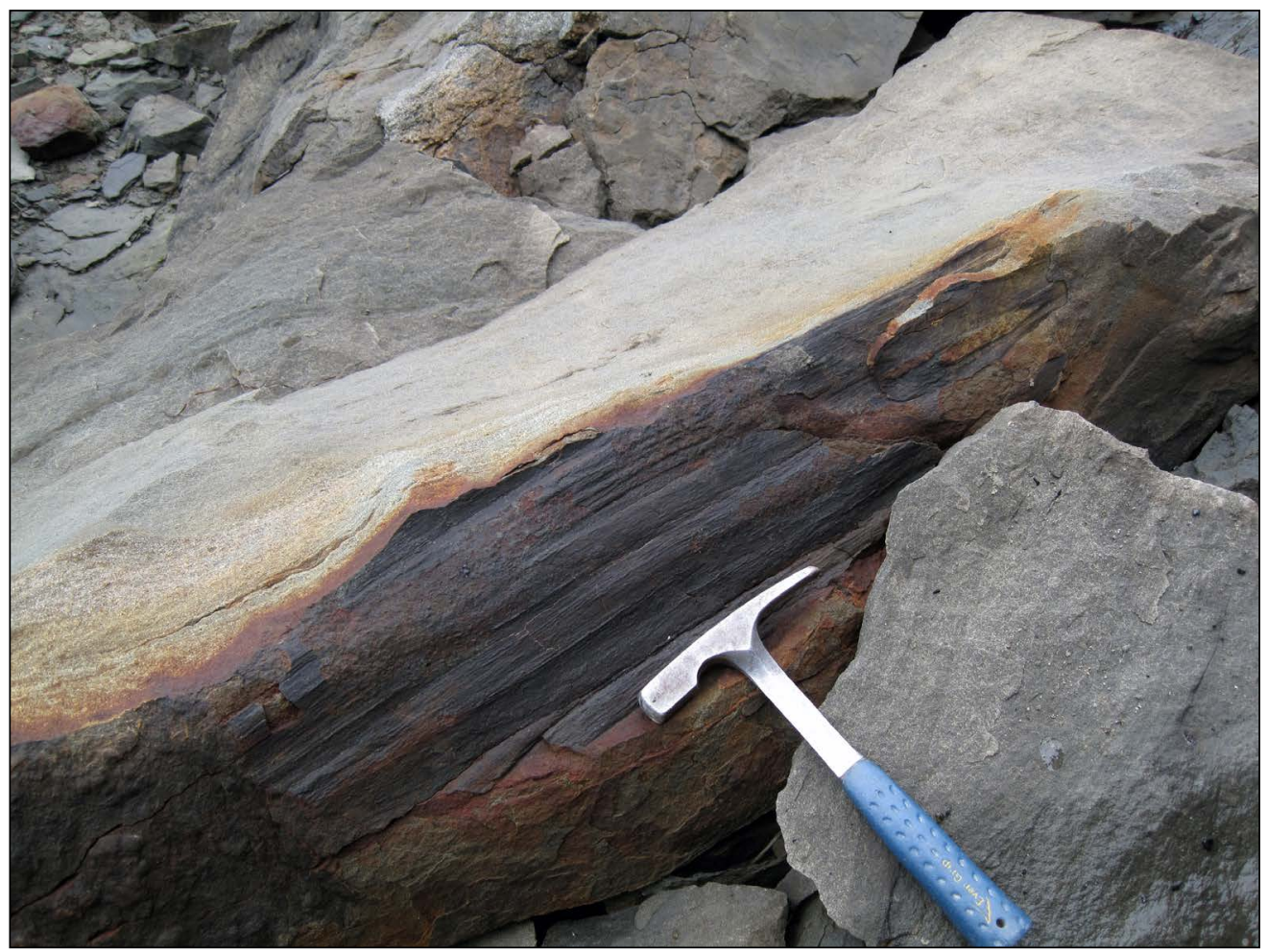

Figure 22. Fragment of flattened log in sandstone about $28 \mathrm{~m}$ stratigraphically below the hydrocarbon-bearing sandstone in figure 3. Rock hammer is about $30 \mathrm{~cm}$ long. Photo by Rick Stanley (USGS), 2012.

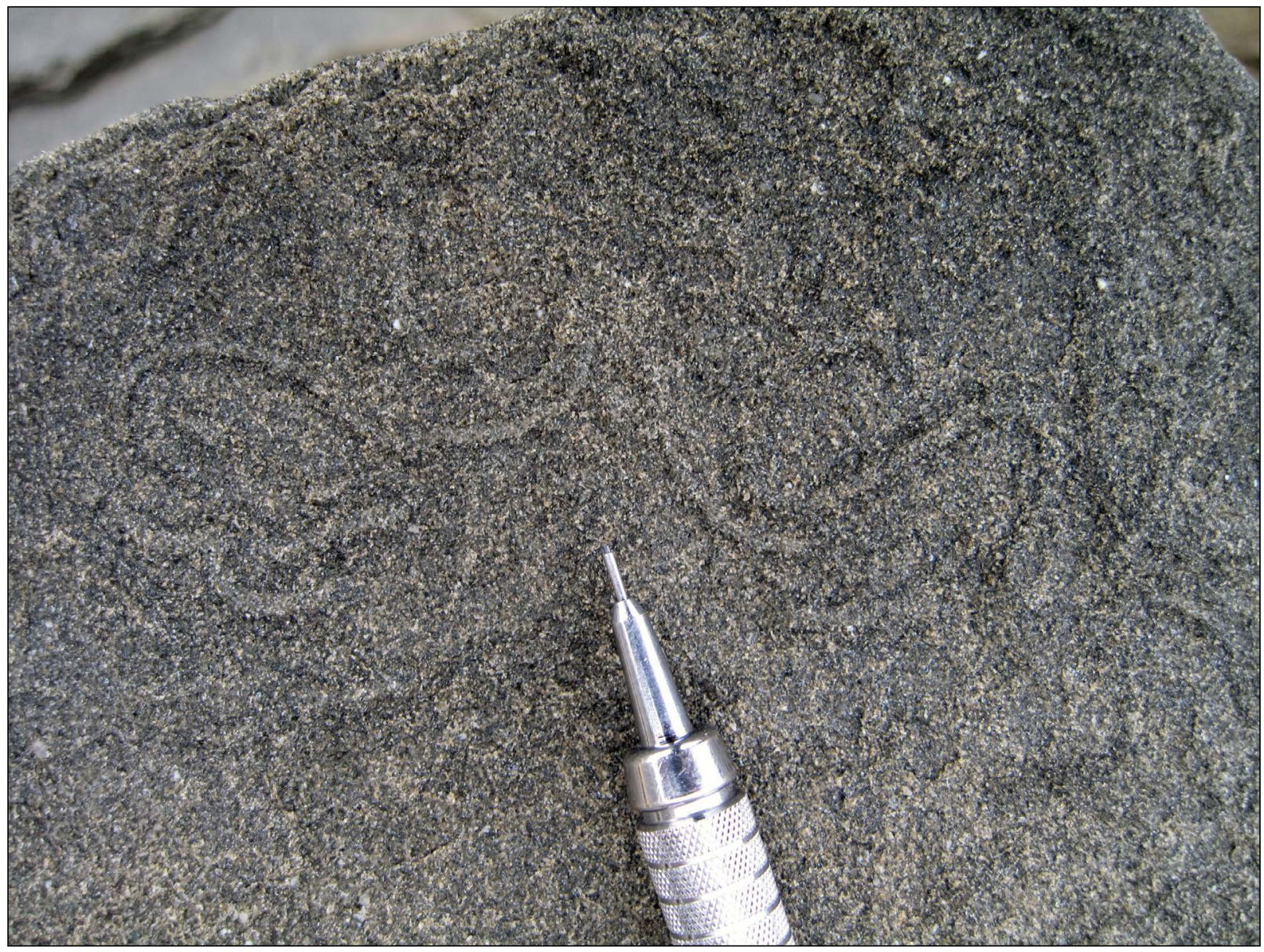

Figure 23. Ichnofossils in sandstone, possibly Macaronichnus segregatis, in a float block about $20 \mathrm{~m}$ stratigraphically below the hydrocarbon-bearing sandstone in figure 3. Barrel of pencil is about $1 \mathrm{~cm}$ diameter. Photo by Rick Stanley (USGS), 2012. 


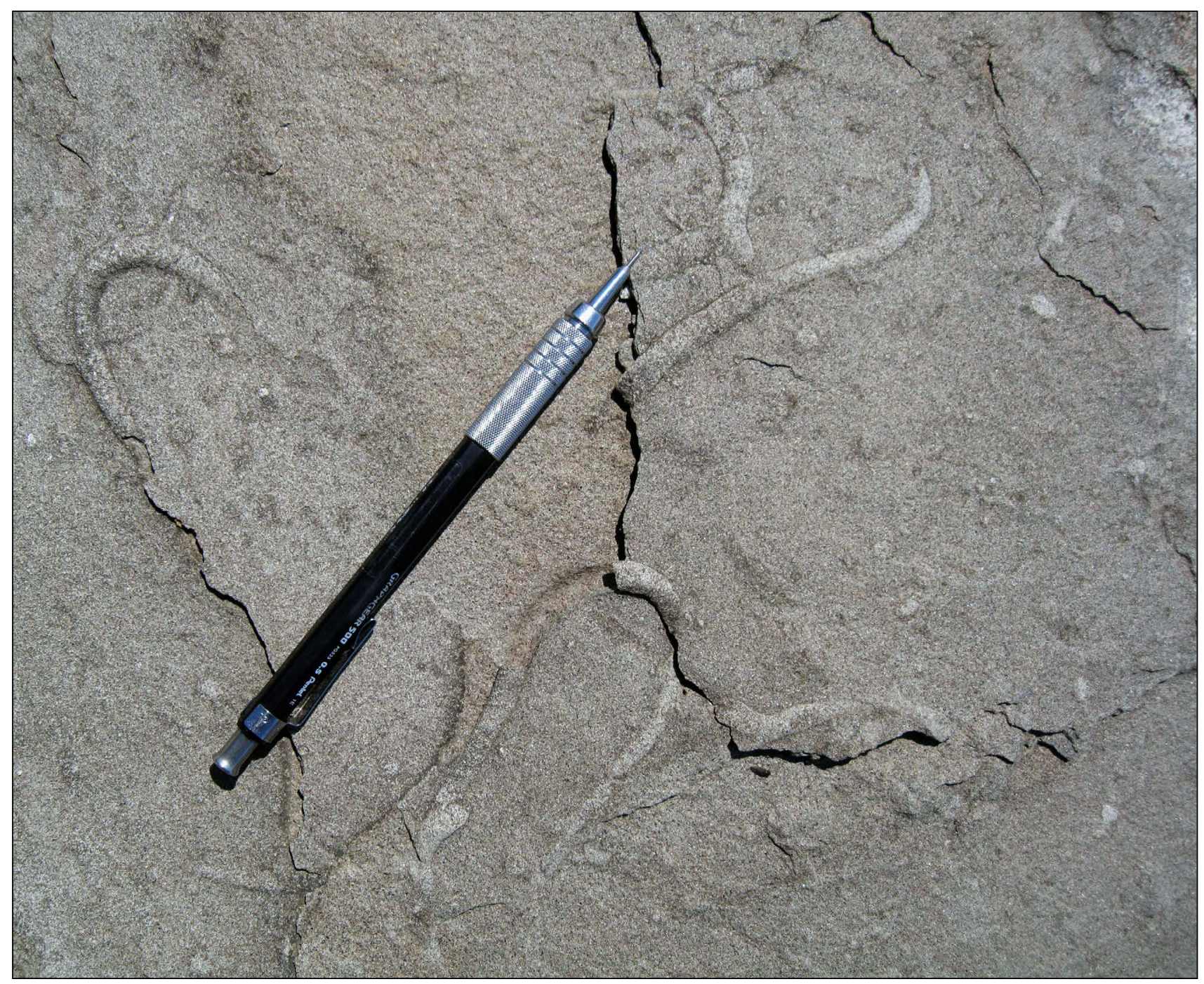

Figure 24. Ichnofossils in sandstone, probably Planolites, in a float block about $2 \mathrm{~m}$ stratigraphically below the hydrocarbonbearing sandstone in figure 3. Pencil is about $14 \mathrm{~cm}$ long. Photo by Rick Stanley (USGS), 2012. 